\title{
STUDY OF DES-GAMMA-CARBOXYPROTHROMBIN (DCP) LEVELS IN CHRONIC HEPATITIS C WITH OR WITHOUT HEPATOCELLULAR CARCINOMA (HCC) IN EGYPTIAN PATIENTS
}

\author{
By \\ Soheir S.Maklad*; Adel Ahmed SM. EL-Sahar**; Iman Hassan Ibrahim***; Omnia \\ AM. Kamel***

\section{FROM} \\ Department of Microbiology, Faculty of Medicine (Girls), Al-Azhar University* \\ Department of Tropical Medicine, Faculty of Medicine (Boys), AL-Azhar University** \\ Department of Biochemistry, Faculty of Pharmacy (Girls), AL-Azhar University***
}

\begin{abstract}
Hepatocellular carcinoma (HCC) is usually asymptomatic in the early stage and does not show elevated alpha-feto protein (AFP). Des-Gamma-CarboxyProthrombin (DCP) and Carbohydrate antigen 19-9 (CA19-9) may increase in sera of HCC patients. The ultimate goal is to evaluate the potential role of DCP and CA19-9 compared to AFP as early diagnostic, non-invasive markers for chronic hepatitis $\mathrm{C}$ patients with and without HCC. 26 chronic HCV patients, $26 \mathrm{HCC}$ related to HCV and 25 normal controls were studied. Quantitative determination of AFP, DCP and CA19-9 concentrations in sera was done using commercially available Enzyme-linked Immunosorbent Assay (ELISA) kits. Results: In HCC patients, AFP showed the highest diagnostic accuracy $(90.2 \%)$ followed by DCP $(80.4 \%)$ and CA19-9 $(70.6 \%)$. AFP showed the highest specificity and sensitivity (100\%-80.8\%). DCP and CA19-9 showed the same specificity $(92 \%)$ but DCP showed higher sensitivity (69.2\%) than CA19-9 (50\%). In HCV patients, CA19-9 showed the highest diagnostic accuracy (74.5\%) followed by DCP (70.6\%). AFP showed the lowest diagnostic accuracy (58.8\%).Both CA19-9 and DCP showed highest specificity (100\%), AFP is the lowest (84\%). CA19-9 showed the highest sensitivity (50\%), followed by DCP $(42.3 \%)$ and AFP (34.6\%). Significant higher levels of DCP and CA-19-9 were detected in HCC patients with low AFP levels $(\mathrm{P}<0.05)$. Conclusion: Serum levels of DCP and CA19-9 could be used as sensitive tumor markers to detect HCV patients with HCC and also to detect $\mathrm{HCV}$ patients who are at risk to develop cancer.
\end{abstract}

\section{INTRODUCTION}

Four percent of the world's population are chronically infected with HCV and as many as $30 \%$ of it will develop cirrhosis within 20 years of infection and a large subset will subsequently develop liver failure and/or hepatocellular carcinoma (Bostan and Mahmood, 2010). Hepatocellular carcinoma (HCC) is a major health problem 
(Jain et al., 2010). The burden of HCC has been increasing in Egypt with a doubling in the incidence rate in the past 10 years (Mizokami and Tanaka 2005). The lack of symptoms in the early stage of HCC makes its early diagnosis impractical (Stefaniuk et al., 2010). Serum level of AFP is the commonly used to screen for liver cancer, however false negative rate is quite high in the early stage HCC. Even in chronic HCC the AFP level found to be normal in $15-30 \%$ of patients (Singhal et al., 2012). The early detection of patients at the highest risk for developing HCC (such as HCV patients) may decrease HCC mortality and reduce medical costs (Mao et al., 2010). Des-Gamma-CarboxyProthrombin (DCP) which is abnormal prothrombin induced vitamin K-II (PIVKA) that results from an acquired defect the post-translational carboxylation of the prothrombin precursor in malignant cells was found to be increased in the serum of HCC patients (Marrero et al., 2009). Carbohydrate Antigen or cancer antigen (CA19-9) is a mucinic type glycoprotein. It is reasonable that any noxa (viral or toxic) which is able to promote tissue inflammatory damage and, sequentially, reparative features with fibrotic tissue deposition and parenchymal regeneration can induce CA19.9 synthesis (Schöniger-Hekele and Müller, 2006).The present study investigates the potential role of serum DCP and CA19-9 compared to AFP as early diagnostic, non-invasive markers in chronic HCV patients with and without HCC.

\section{SUBJECTS}

A total of 77 subjects were involved in the study. They were classified into 3 groups: 26 patients with HCC related to chronic HCV [18 males and 8 females], 26 patients with chronic HCV [17 males and 9 females] and 25 normal controls [17 males and 8 females]. Patients were selected consecutively among patients presented to the Tropical Medicine Department of Al-Hussein and Sayed Galal hospitals during the period from May 2013 to April 2014. Inclusion criteria: HCC related to chronic HCV patients diagnosed according to clinical examination, radiological investigations including abdominal ultrasonography, triphasic C.T and laboratory investigations, HCV patients (with or without liver cirrhosis) diagnosed on the basis of clinical assessment and laboratory investigations such PCR and Healthy volunteers negative for HCV and HBV nucleic acid. Exclusion criteria: HCC related to HBV or any other cause or any other tumors, HCV combined with HBV, patients with any type of tumor or patients treatment with interferon. SAMPLE: Five ml venous blood samples were collected from each subject in serum sample separator tubes. Blood samples were allowed to clot for two hours at room temperature before centrifugation for 20 minutes at approximately $1000 \mathrm{rpm}$ and then sera were stored in aliquot at $-80^{\circ} \mathrm{C}$. METHODS: ELISA technique was used to measure serum concentrations of AFP Abdel-Hamid et al., 2014), DCP (Abdel-Hamid et al., 2014) and CA19-9 (Markocka-Maczka,2003) according to manufacturers' instructions, AFP (Pointe Scientific, USA), DCP (Glorybiosience, china), CA19-9 (Immunospec Corporation, USA). 


\section{STATISTICAL ANALYSIS:}

Values were presented as mean $\pm \mathrm{SD}$, median and range. Data were analyzed Fisher's exact test, Student's t-test, Kruskal-Wallis test and Spearman's correlation coefficient was used to determine significant correlations between different markers. $\mathrm{P}$ value of less than 0.05 was considered statistically significant. ROC (Receiver Operating Characteristic) curve was constructed to evaluate diagnostic accuracy measures of different markers. Areas under the ROC curve (AUCs) of the different markers were compared using z-statistic

\section{RESULTS:}

The mean concentrations of serum AFP, DCP and CA19-9 were determined in 26 patients with $\mathrm{HCC}$ related to $\mathrm{HCV}, 26$ patients with $\mathrm{HCV}$ without $\mathrm{HCC}$ and 25 normal controls. The studied patients aged 30-80 years old. There was an insignificant male predominance among both $\mathrm{HCC}$ and $\mathrm{HCV}$. The mean value of $\mathrm{AFP}(\mathrm{ng} / \mathrm{ml})$ was significantly increased only in HCC patients $(7290.5 \pm 12541.8)$ compared to chronic HCV patients $(4.5 \pm 4.6)$ and controls $(4.8 \pm 3.9) ;(\mathrm{p}<0.001)$. The mean values of serum DCP showed significant differences between the three studied groups $(\mathbf{P}<\mathbf{0 . 0 0 1})$. The mean value of DCP $(\mathrm{mAU} / \mathrm{ml})$ was significantly increased in HCC $(1451.2 \pm 1019.4)$ and HCV patients (1309.5 \pm 975.1$)$ compared to controls $(915.1 \pm 210.3),(\mathrm{P}<0.05)$. The mean value of CA19-9 (U/ml) was significantly increased among HCC patients (196.7 \pm 453.3$)$ and HCV patients $(79.8 \pm 120.9)$ compared to controls $(11.4 \pm 9.7)$ ). There was a significant difference in CA19-9 serum levels between the three studied groups $(\mathrm{p}<0.001)$ (fig.1).

HCC patients were classified into 2 subgroups according to the level of AFP which is considered as the gold standard into: $<200 \mathrm{ng} / \mathrm{ml}$ and $>200 \mathrm{ng} / \mathrm{ml}$ according to (Zhu et al., 2013). It was found that $8(30.8 \%)$ of HCC patients and $100 \%$ of both chronic HCV and normal controls had AFP levels $<200 \mathrm{ng} / \mathrm{ml}$. Among the 8 patients with AFP levels $<200 \mathrm{ng} / \mathrm{ml}: 4(50 \%)$ had DCP high levels $>1054$ with mean of $(1469 \pm 768.3) \mathrm{mAU} / \mathrm{ml}$ and $6(75 \%)$ had high CA19-9 levels $>25 \mathrm{U} / \mathrm{L}$ mean (264.4 \pm 492.9$)$, (table 1). In HCC group cut-off values were $1054 \mathrm{mAU} / \mathrm{ml}, 16 \mathrm{ng} / \mathrm{ml}$ and $25.2 \mathrm{U} / \mathrm{ml}$ for DCP, AFP and CA19-9 respectively. AFP showed the highest diagnostic accuracy (90.2\%) followed by DCP (80.4\%). CA19-9 showed the lowest diagnostic accuracy (70.6\%). AFP showed the highest specificity and sensitivity (100\%-80.8\%). DCP and CA19-9 showed the same specificity (92\%) but DCP showed higher sensitivity (69.2\%) than CA19-9 (50\%). In HCV group cut-off values were $1075 \mathrm{mAU} / \mathrm{ml}, 1.7 \mathrm{ng} / \mathrm{ml}$ and $32.0 \mathrm{U} / \mathrm{ml}$ for DCP, AFP and CA19-9 respectively. CA19-9 showed the highest diagnostic accuracy (74.5\%) followed by DCP (70.6\%). AFP showed the lowest diagnostic accuracy (58.8\%). Both CA19-9 and DCP showed the same high specificity (100\%) and AFP showed the lowest specificity (84\%). CA199 showed the highest sensitivity (50\%), Followed by DCP (42.3\%), AFP showed the lowest sensitivity (34.6\%). In addition, DCP showed the highest AUC (0.941) (0.738) 
followed by CA19-9 (0.721), while AFP showed the lowest AUC (0.601). According to HCC group there is no significant correlation between the different markers (AFP, DCP, and CA19-9).

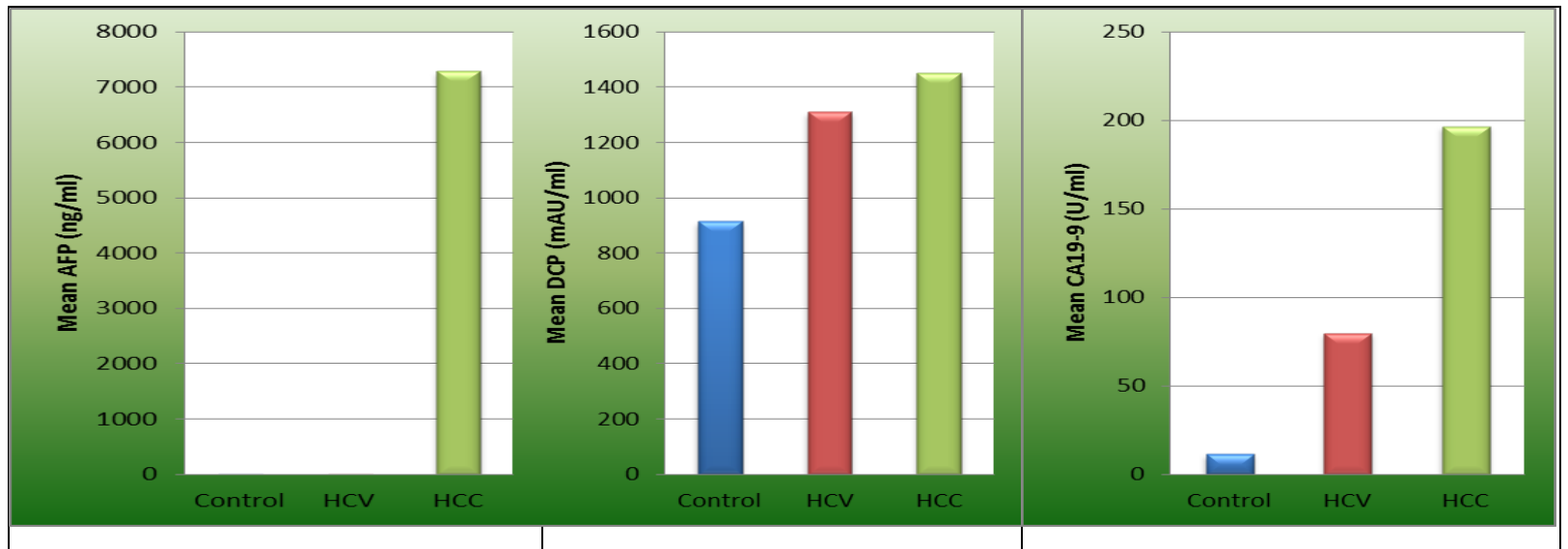

Figure (1): The mean AFP, DCP and CA19-9 concentrations in the three groups.

Table (1): Relation between DCP, CA19-9 and AFP in HCC group:

\begin{tabular}{|c|c|c|c|c|c|c|c|}
\hline $\begin{array}{l}\mathbf{A F P} \\
/ \mathbf{D C P}\end{array}$ & $\begin{array}{l}\text { AFP }<200 \\
\text { ng/ml } \\
8(30.8 \%)\end{array}$ & $\begin{array}{l}\text { AFP> } 200 \\
\mathbf{n g} / \mathbf{m l} \\
18(69.2 \%)\end{array}$ & $\begin{array}{l}\text { p- } \\
\text { value }\end{array}$ & $\begin{array}{l}\text { AFP } \\
/ \text { CA19-9 }\end{array}$ & $\begin{array}{l}\text { AFP <200 } \\
\mathbf{n g} / \mathbf{m l} \\
8(30.8 \%)\end{array}$ & $\begin{array}{l}\text { AFP>200 } \\
\mathbf{n g} / \mathbf{m l} \\
18(69.2 \%)\end{array}$ & $\begin{array}{l}p- \\
\text { value }\end{array}$ \\
\hline $\begin{array}{l}\mathbf{D C P}(\mathbf{m} \\
\text { AU/ml }) \\
\text { Range } \\
\text { Median } \\
\text { Mean } \pm \text { SD }\end{array}$ & $\begin{array}{l}(823.0- \\
2621) \\
1055 \\
1218 \pm 573.9\end{array}$ & $\begin{array}{l}(893.0- \\
5333) \\
1115 \\
1555 \pm 1164\end{array}$ & $>0.05$ & $\begin{array}{l}\text { CA19- } \\
\text { 9((U/ml) } \\
\text { Range } \\
\text { Median } \\
\text { Mean } \pm \text { SD }\end{array}$ & $\begin{array}{l}(0.9000- \\
1643) \\
17.80 \\
195.7 \pm 474.0\end{array}$ & $\begin{array}{l}(1.800- \\
1268) \\
46.60 \\
198.9 \pm 433.9\end{array}$ & $>0.05$ \\
\hline $\begin{array}{l}\text { DCP } \leq 1054 \\
\mathbf{N}(\%) \\
\text { Range } \\
\text { Median } \\
\text { Mean } \pm \text { SD } \\
\text { DCP>1054 } \\
\mathbf{N}(\%) \\
\text { Range } \\
\text { Median } \\
\text { Mean } \pm \text { SD }\end{array}$ & $\begin{array}{l}4(50 \%) \\
(823-1044) \\
999 \\
966.3 \pm 98.59 \\
4(50 \%) \\
(1065-2621) \\
1095 \\
1469 \pm 768.3\end{array}$ & $\begin{array}{l}4(22.22 \%) \\
(893.0- \\
1054) \\
1019 \\
996.3 \pm 70.90 \\
14(77.78 \%) \\
(1065-5333) \\
1145 \\
1715 \pm 1284\end{array}$ & $<0.05 *$ & $\begin{array}{l}\text { CA19- } \\
\mathbf{9} \leq \mathbf{2 5} \\
\mathbf{N}(\boldsymbol{\%}) \\
\text { Range } \\
\text { Median } \\
\text { Mean } \pm \text { SD } \\
\\
\text { CA19- } \\
\mathbf{9 > 2 5} \\
\mathbf{N}(\%) \\
\text { Range } \\
\text { Median } \\
\text { Mean } \pm \text { SD }\end{array}$ & $\begin{array}{l}2(25 \%) \\
(1.800-2.700) \\
2.250 \\
2.250 \pm 0.6364 \\
\\
6(75 \%) \\
(27.50-1268) \\
67.80 \\
264.4 \pm 492.9\end{array}$ & $\begin{array}{l}11(61.11 \%) \\
(0.9000- \\
21.00) \\
13.70 \\
10.92 \pm 7.649 \\
\\
7(38.89 \%) \\
(28.00- \\
1643) \\
86.00 \\
486.1 \pm 689.5\end{array}$ & $<0.05 *$ \\
\hline
\end{tabular}

*: Significant at $\mathrm{P} \leq 0.05$ 
Table (2): Sensitivity, specificity, predictive values, diagnostic accuracy, Area under the ROC curve (AUC), standard error (SE) and $95 \%$ confidence interval $(95 \% \mathrm{CI})$ of the three markers

\begin{tabular}{|c|c|c|c|c|c|c|c|c|}
\hline Marker & $\begin{array}{l}\text { Sensitiv } \\
\text { ity } \%\end{array}$ & $\begin{array}{l}\text { Specificit } \\
\text { у } \%\end{array}$ & $\begin{array}{l}+\mathrm{PV} \\
\%\end{array}$ & $\begin{array}{l}-\mathrm{PV} \\
\%\end{array}$ & $\begin{array}{l}\text { Diagnosti } \\
\text { c } \\
\text { accuracy } \\
\%\end{array}$ & $\mathbf{A U C}$ & SE & $95 \% \mathrm{CI}$ \\
\hline $\begin{array}{l}\text { HCCVs. } \\
\text { control } \\
\text { DCP } \\
\text { AFP } \\
\text { CA19-9 }\end{array}$ & $\begin{array}{l}69.2 \\
80.8 \\
50.0\end{array}$ & $\begin{array}{l}92.0 \\
100.0 \\
92.0\end{array}$ & $\begin{array}{l}90.0 \\
100 . \\
0 \\
86.7\end{array}$ & $\begin{array}{l}74.2 \\
83.3 \\
63.3\end{array}$ & $\begin{array}{l}80.4 \\
90.2 \\
70.6\end{array}$ & $\begin{array}{l}0.861 \\
0.941 \\
0.721\end{array}$ & $\begin{array}{l}0.05 \\
0.03 \\
0.07\end{array}$ & $\begin{array}{c}0.735-0.942 \\
0.837-0.988 \\
0.578-0.837\end{array}$ \\
\hline $\begin{array}{l}\text { HCV } \\
\text { control } \\
\text { DCP } \\
\text { AFP } \\
\text { CA19-9 }\end{array}$ & $\begin{array}{l}42.3 \\
34.6 \\
50.0\end{array}$ & $\begin{array}{l}100.0 \\
84.0 \\
100.0\end{array}$ & $\begin{array}{l}100 . \\
0 \\
69.2 \\
100 . \\
0\end{array}$ & $\begin{array}{l}62.5 \\
55.3 \\
65.8\end{array}$ & $\begin{array}{l}70.6 \\
58.8 \\
74.5\end{array}$ & $\begin{array}{l}0.738 \\
0.601 \\
0.721\end{array}$ & $\begin{array}{l}0.07 \\
0.08 \\
0.07\end{array}$ & $\begin{array}{l}0.596-0.851 \\
0.454-0.735 \\
0.578-0.837\end{array}$ \\
\hline $\begin{array}{l}\text { HCC } \\
\text { HCV } \\
\text { DCP } \\
\text { AFP } \\
\text { CA19-9 }\end{array}$ & $\begin{array}{l}80.8 \\
80.8 \\
76.9\end{array}$ & $\begin{array}{l}42.3 \\
100.0 \\
34.6\end{array}$ & $\begin{array}{l}58.3 \\
100 . \\
0 \\
54.1\end{array}$ & $\begin{array}{l}68.7 \\
83.9 \\
60.0\end{array}$ & $\begin{array}{l}61.1 \\
89.4 \\
55.4\end{array}$ & $\begin{array}{l}0.593 \\
0.945 \\
0.496\end{array}$ & $\begin{array}{l}0.08 \\
0.03 \\
0.08\end{array}$ & $\begin{array}{c}0.448-0.727 \\
0.844-0.989 \\
0.355-0.638\end{array}$ \\
\hline
\end{tabular}


Table (3): Correlation coefficient between different markers in HCC group

\begin{tabular}{l|ll}
\hline Markers & $\begin{array}{l}\text { Correlation } \\
\text { coefficient (r) }\end{array}$ & P-value \\
\hline DCP \& AFP & 0.266 & 0.188 \\
DCP \& CA19-9 & -0.090 & 0.661 \\
AFP \& CA19-9 & -0.178 & 0.384 \\
\hline *. Significant at P $\leq 0.05$
\end{tabular}

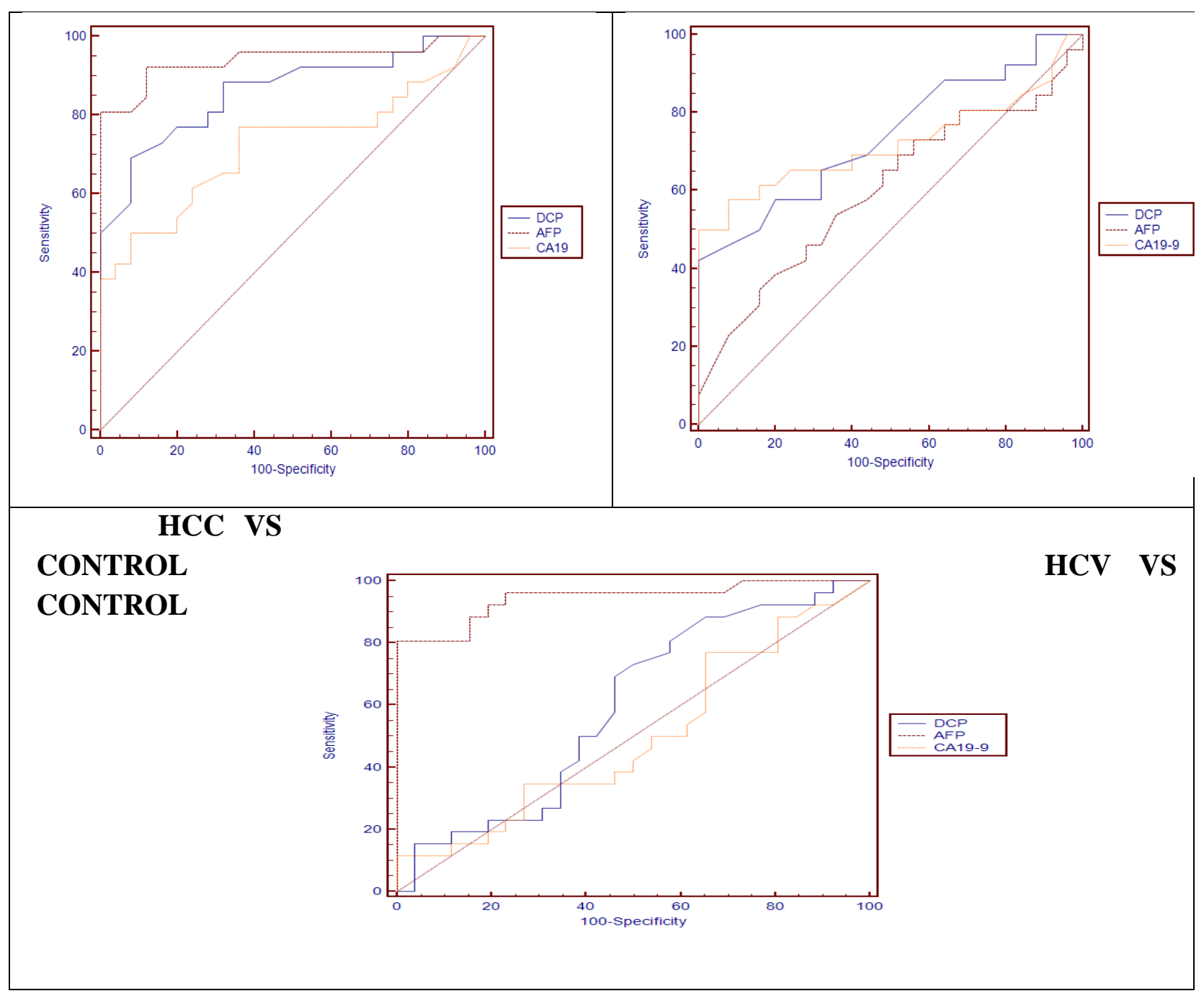

HCC VS HCV

Figure (2): ROC curve for the different markers: 


\section{DISCUSSION}

About $85 \%$ of $\mathrm{HCV}$ patients develop persistent infection and are at risk of longterm complications including liver cirrhosis and hepatocellular carcinoma (HCC) (Berry et al., 2006). The lack of symptoms in the early stage of HCC makes its early diagnosis impractical (Jenget al., 2012). Therefore, reliable diagnostic biomarkers are urgently needed to improve clinical outcomes (Shen et al., 2012). In the current study a significant difference in AFP serum levels between HCC group and controls was observed and also between HCC and chronic HCV groups while insignificant difference between HCV group and controls. These results are similar to the study of Kim et al., (2013) who found that in patients with liver Cancer AFP serum levels were exceeded its normal levels. In addition, Zachary et al., (2012) reported that the concentration of AFP is significantly higher in patients with HCC than patients with benign liver diseases and control subjects. The finding that DCP is increased significantly in HCV with HCC and also in HCV patients without HCC (most of them have cirrhosis) than the normal controls is similar to the study of (Abd El Gawad et al., 2014) who found that DCP is significantly higher in the HCC followed by cirrhosis then the normal control groups.

In another study a significant elevation in DCP levels was revealed in the HCC group compared to the benign and normal control groups (Zachary et al, 2012). In the present study, CA19-9 was significantly elevated in HCC patients and in HCV patients (most with cirrhosis) compared to controls. Other investigators reported that CA19-9 levels in chronic hepatitis and related cirrhosis was statistically significant. They concluded that CA19.9 serum levels elevation does not indicate acontemporary neoplastic disease, but correlates in a statistically significant way with the grade of liver fibrosis, appearing to be more evident in patients with higher fibrosis score, thus correlating with the severity of the liver disease (Bertino et al., 2007).

In the current study the cut-off point, for AFP in HCC patient's was $16 \mathrm{ng} / \mathrm{mL}$. Other studies reported that any AFP result $>10 \mathrm{ng} / \mathrm{ml}$ should raise a suspicion of HCC, while an AFP >200 ng/ ml, particularly in the presence of HBVs Ag is highly suggestive of it (Zhu et al., 2013). Other researchers showed that serum levels of AFP above $200 \mathrm{ng} / \mathrm{ml}$ are essential in HCC diagnosis and must be correlated with imaging studies (Leerapun et al., 2007). In the current study, 100\% of chronic HCV group, 30.8\% of HCC patients had AFP serum levels less than $200 \mathrm{ng} / \mathrm{ml}$ and $69.2 \%$ of HCC patients had AFP serum levels more than $200 \mathrm{ng} / \mathrm{ml}$. This represents the gray zone in the diagnosis of HCC (Peng et al., 2004) and can be explained by increase in the degree of inflammation (Bruce et al., 2008). The significant portion of HCC patients (30.8\%) showing a low serum levels of AFP could be explained by; in some patients, high AFP levels are observed only in the early stages and then drop or even fall to the normal range as the disease progresses (Tungand $\mathbf{N g}, \mathbf{2 0 1 2}$ ). The present study revealed that $50 \%$ of HCC patients with low AFP (AFP $<2 \mathrm{OOng} / \mathrm{ml}$ ) have high level of DCP and $75 \%$ of HCC patients with low AFP (AFP $<2$ OOng/ml) have high level of CA19-9. 
Abd El Gawad et al., (2014) on their study on cirrhotic patients found that one of them showed elevated serum levels of DCP while AFP level was $67 \mathrm{ng} / \mathrm{ml}$. This patient was diagnosed as HCC 9 months later, which indicates that DCP can be considered as a sensitive marker for follow up of cirrhotic patients, to detect early development of HCC.DCP is more indicative about the tumor bulk, hence can be more suitable than AFP for earlier diagnosis of HCC (Ozkan et al., 2011). Choi et al. (2013) added that DCP proved to be superior to AFP in early detection of HCC. In our study AFP had high sensitivity and specificity $80 \%$ and $100 \%$ respectively similar to other study which showed that AFP sensitivities and specificities for HCC were 45\%-100\% and 70\%-95\%, respectively, at cut points between 10 and $19 \mu \mathrm{g} / \mathrm{L}$ (Gebo et al., 2002).

Our study also revealed that specificity of DCP was $92 \%$ and sensitivity was $69 \%$ which are similar to that of other studies which showed different sensitivities and specificities for DCP of 62\%-95\% and 53.3\%- 98\%(Marrero et al., 2003). These variations may be due to tumor size, number of masses or to the difference in the number of studied cases. The finding that DCP showed a diagnostic accuracy (82.4\%) less than AFP (90.2) came in agreement with the study of Nakamura et al., (2006) on HCC patients and non-HCC controls with chronic hepatitis or cirrhosis. They showed that the accuracy of DCP was inferior to AFP, particularly for small tumors. Moreover, the finding that AFP was more sensitive and specific than DCP is similar to other reports that showed specificity of DCP lower than that of AFP (72.5\% versus 97.5\%)(Abdel-Hamid et al., 2014). DCP ability to detect HCCs appears to vary substantially depending on tumor characteristics such as vascular invasion and metastases (Bae et al., 2013). These features may explain the variable performance of DCP in different studies. Various factors may influence the performance of AFP and DCP, including patient demographics, cause of underlying liver disease, presence of cirrhosis, tumor stag and tumor biology (Volk et al., 2007).

There was no significant correlation between AFP and DCP these came in agreement with other studies reported that elevated DCP in sera of HCC patients is suggested to have no relation to elevated AFP, so the combination of these two markers significantly improve HCC detection (Sterling et al., 2009).

\section{Conclusion:}

DCP and CA19-9 might be used as tumor markers for HCC patients also may increase in $\mathrm{HCV}$ patients especially with cirrhosis. HCV patients with elevated DCP and CA19-9 serum levels may have an increased risk of HCC. DCP and CA19-9 may be useful in HCC patients with low AFP $(<200 \mathrm{ng} / \mathrm{ml})$ in our study $50 \%$ of HCC patients with low AFP (AFP $<2 \mathrm{OO} \mathrm{ng} / \mathrm{ml}$ ) have high level of DCP and $75 \%$ of HCC patients with low AFP (AFP $<2 \mathrm{OO} \mathrm{ng} / \mathrm{ml}$ ) have high level of CA19-9. 


\section{REFERENCES}

Abd El Gawad AI , Mossallam GI,Radwan NH, Elzawahry HMb, Niveen M. Elhifnawy NM (2014): Comparing Prothrombin induced by vitamin K absenceII (PIVKA-II) with the oncofetal proteins Glypican-3, Alpha feto protein and Carcinoembryonic antigen in diagnosing hepatocellular carcinoma among Egyptian patients, Elhifnawya Journal of the Egyptian National Cancer Institute 26, 79-85

Abdel-Hamid NM, Wahid AM, Anbar NH and Helaly T (2014): Estimation of Desgamma-carboxy prothrombin with Alpha Fetoprotein Elevates the Diagnostic Performance of Hepatocellular Carcinoma among Upper Egyptian Hepatitis C Patients, Research Journal of Pharmaceutical, Biological and Chemical Sciences, 821-831

Bae HM, Lee JH, Yoon JH, Kim YJ, DaeHeo S, Lee HS (2013):.Protein induced by vitamin $\mathrm{K}$ absence or antagonist-II production is a strong predictive marker for extrahepatic metastases in early hepatocellular carcinoma: a prospective evaluation. BMC cancer, 11: 435-442.

Berry V, Arora R and Paul P (2006): Hepatitis C-Clinical Outcome and Diagnosis. JK Scince, 7(3):129 - 132.

Bertino G1, Ardiri AM, Boemi P, Bruno CM, Valenti M, Mazzarino MC, Consolo M, Calvagno GS, Pulvirenti D, Neri S. (2007): Meaning of elevated CA19-9 serum levels in chronic hepatitis and HCV-related cirrhosis. Minerva Gastroenterol Dietol ; 53(4): 305-309.

Bostan N and Mahmood T (2010): An overview about hepatitis Cadevastating virus. Crit Rev Microbiol.; 36: 91-133

Bruce M, Bruden D, McMahon B, Christensen C, Homan C, Sullivan D, Deubner H, Williams J, Livingston S and Gretch D (2008): Clinical significance of elevated alpha-fetoprotein in Alaskan Native patients with chronic hepatitis C. Journal Viral Hepatology, 15(3):179-187.

Cahill B and Braccia D (2004): Current treatment for hepatocellular carcinoma. Clin J OncolNurs., 8(4):393-399.

Choi J, Jung S, Kim H, Kim M, Kim Y, Kim D, Oh EJ (2013): Diagnostic value of AFP and PIVKA-II in HCC according to total-AFP. World J Gastroenterol; 19(3):339-346. 
El- Abd Y, Tabll A, El Din N, Hosny A, Moustafa R, El-Shenawy R, Atef K and El-Awady M (2011): Neutralizing activities of caprine antibodies towards conserved regions of the HCV envelope glycoprotein E2.Virol J., 8:391-403.

Gebo KA, Chander G, Jenckes MW, Ghanem KG, Herlong HF, Torbenson MS, El-Kamary SS, Bass EB (2002): Screening tests for hepatocellular carcinoma in patients with chronic hepatitis C: a systematic review. Hepatology; 36:S84S92.

Jain S, Singhal S, Lee P, Xu R (2010): Molecular genetics of hepatocellular neoplasia. Am J Transl Res; 2(1):105-118.

Jeng J, Chuang L, Chuang W and Tsai J (2012): Serum Dickkopf-1 as a biomarker for the diagnosis of hepatocellular carcinoma. Chin ClinOncol.1 (1):1-3.

Kim H, Kim K, Yu S, Jang E, Yu J, Yoon J and Kim Y (2013): Development of Biomarkers for Screening Hepatocellular Carcinoma Using Global Data Mining and Multiple Reaction Monitoring.PLoS ONE, 8(5): 1-25.

Leerapun A, Suravarapu S and Bida J (2007): The utility of Lens culinaris agglutinin-reactive alpha-fetoprotein in the diagnosis of hepatocellular carcinoma: evaluation in a United States referral population. ClinGastroenterolHepatol.,5 (3):394-402.

Mao Y, Yang H, Xu H, Lu X, Sang X, Du S, Zhao H, Chen W, Xu Y, Chi T, Yang Z, Cai J, Li H, Chen J, Zhong S, Mohanti SR, Lopez-Soler R, Millis JM, Huang J, Zhang H (2010): Golgi protein 73 (GOLPH2) is a valuable serum marker for hepatcellular carcinoma. Gut, doi10.1136/gut. 214916.

Markocka-Maczka K (2003): Ca 19-9 antigen in differentiation of pancreatic inflammatory and neoplastic tumors, Wiad Lek. 56(11-12):537-40

Marrero JA, Su GL, Wei W, Emick D, Conjeevaram HS, Fontana RL,Lok AS (2003): Des gamma carboxyprothrombin can differentiate hepatocellular carcinoma from nonmalignant chronic liver disease in American patients. Hepatology. 37: 1114-1121.

Marrero J, Feng Z, Wang Y, Nguyen M, Befeler A, Roberts LR, Reddy KR, Harnois $\quad$ D, Llovet JM, Normolle $\quad$ D, Dalhgren J, Chia $\quad$ D, Lok AS, Wagner PD, Srivastava S, Schwartz M(2009): Alfa-feto protein, desgamma carboxyprothrombin, and lectin-bound alpha-feto protein in early hepatocellular carcinoma. Gastroenterology; 137(1):110-118. 
Mizokami M, Tanaka Y (2005): Tracing the evolution of hepatitis $C$ virus in the United States, Japan and Egypt by using the molecular clock. Clin GastroenterolHepatol; 3(10 Suppl2):82-85.

Nakamura S, Nouso $\quad$ K, Sakaguchi $\quad$ K, Ito $\quad$ YM, Ohashi $\quad$ Y, Kobayashi Y, ToshikuniN,Tanaka H, Miyake Y, Matsumoto E, Shiratori $\quad$ Y. (2006).Sensitivity and specificity of des-gamma-carboxyprothrombin for diagnosis of patients with hepatocellular carcinoma varies according to tumor size, American Journal of Gastroenterology, 101:2038-2043.

Ozkan H, Erdal H, Koc ak E, Tutkak H, Karaeren Z, Yakut M, Köklü S (2011): Diagnostic and prognostic role of serum glypican3 in patients with hepatocellular carcinoma. J Clin Lab Anal; 25(5):350-3.

Peng SY, Chen WJ and Lai PL (2004): High alpha-fetoprotein level correlates with high stage, early recurrence and poor prognosis of hepatocellular carcinoma: significance of hepatitis virus infection, age, p53 and beta-catenin mutations. Int J Cancer, 112:44-50.

Raphael S, Yangde Z and YuXiang C (2012): Hepatocellular Carcinoma: Focus on Different Aspects of Management. ISRN Oncology, 1-12.

Schöniger-Hekele M and Muler C (2006): The combined elevation of tumor marker CA19-9 and CA125 in liver disease patients is highly specific for severe liver fibrosis. Dig Dis Sci. 51(2); 338-345.

Shen Q, Fan J, Yang X, Tan Y, Zhao W, Xu Y, Wang N, Niu Y, Wu Z, Zhou J, Qiu S, Shi Y, Yu B, Tang N, Chu W, Wang M, Wu J, Zhang Z, Yang S, Gu J, Wang $H$ and Qin W (2012): Serum DKK1 as a protein biomarker for the diagnosis of hepatocellular carcinoma: a large-scale, multicentre study. Lancet Oncology, 13(8): 817-826

Singhal A, Jayaraman M., DhanasekaranDN ,Kohli V (2012): Molecular and serum markers in hepatocellular carcinoma: predictive tools for prognosis and recurrence. Crit. Rev. Oncol. Hematol. 82 (2), 116-140.

Stefaniuk P, Cianciara J, Wiercinska-Drapalo A (2010): Present and future possibilities for early diagnosis of hepatocellular carcinoma. World $\mathrm{J}$ Gastroenterol 0; 16:418-24.

Sterling RK, Jeffers L, Gordon F,Venook AP, Reddy KR, Satomura S, Kanke F, Schwartz ME, Sherman M(2009): Utility of Lens culinaris agglutinin-reactive fraction of alphafetoproteinand des-gamma-carboxyprothrombin, alone or in 
combination, as biomarkers for hepatocellular carcinoma," Clinical Gastroenterology and Hepatology, 7, pp. 104-113.

Tung EK and Ng IO (2012): Biomarker for HCC diagnosis. Chin ClinOncol., 1:5.

Volk ML,Hernandez JC, Su GL, Lok AS, Marrero JA (2007): Risk factors for hepatocellular carcinoma may impair the performance of biomarkers: a comparison of AFP, DCP, and AFP-L3. Cancer Biomark 3:79-87.

Zachary, Khodeer S, Ezzat H, Abdel Malak C (2012): Impact of PIVKA-II in diagnosis of hepatocellular carcinoma. International Conference on Ecological, Environmental and Biology Sciences, 7-8.

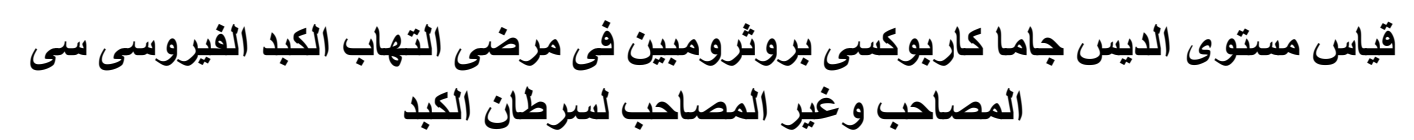

لادمة الدكاتزة

سهير مقلد *عادل احمد السحار ***، ايمان حسن ابر اهيم***، امنيه احمد محمد كامل****

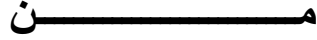

$$
\begin{aligned}
& \text { قسم الميكروبيولوجى- كليه الطب(بنات)-جامعة الأزهر * } \\
& \text { قعم الكبد و الجهاز الهضمى- كلية الطب(بنين)-جامعة الأزهر ** } \\
& \text { ق*م الكيمياء الحيويةـ كلية الصبدلة(بنات)-جامعة الأزهر ** }
\end{aligned}
$$

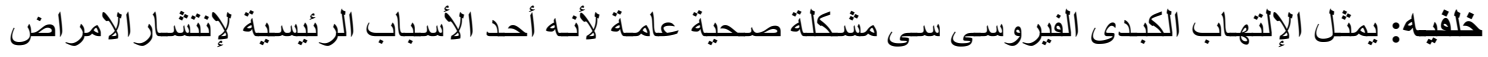

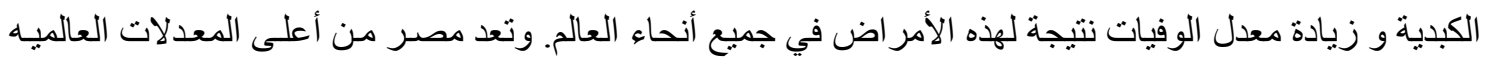

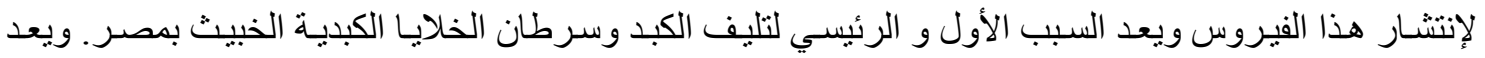

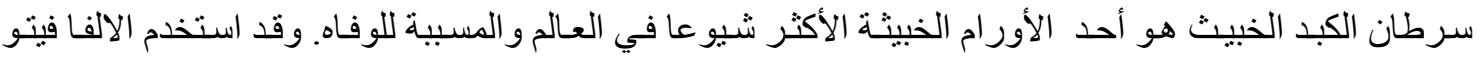

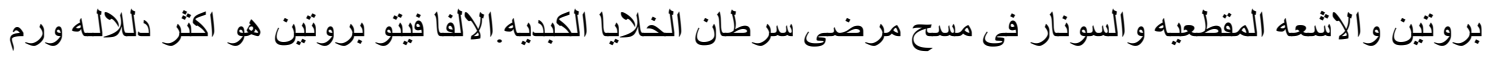

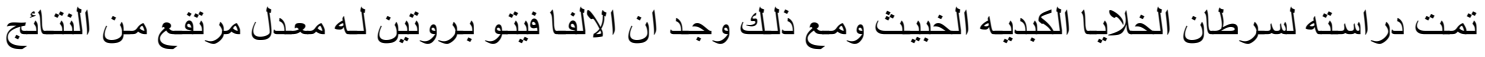

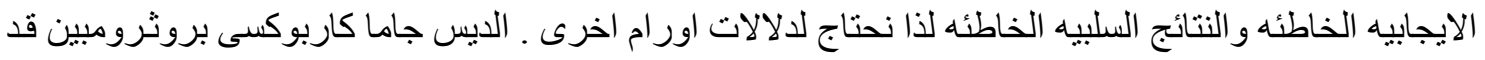

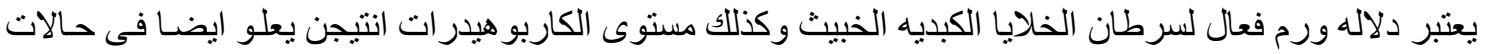
حميده وكنللك حالات خبيثه.19-9 دئل

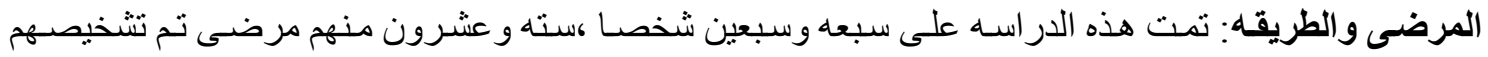

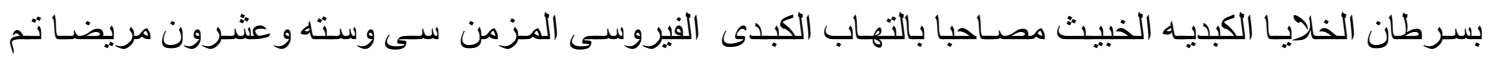

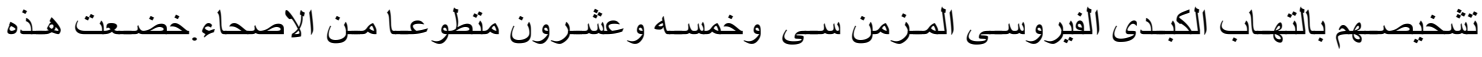

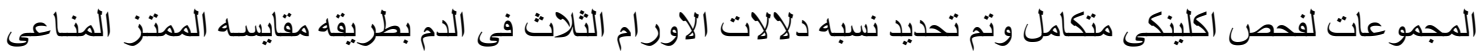

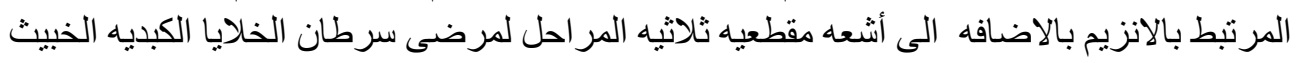


نواتج الاراسه: ليس هنالك اى دلاله احصائيه للعمر و النوع فى المجمو عات الثثلاث.فى هذه الدر اسـهـ وجد ان الآلفا

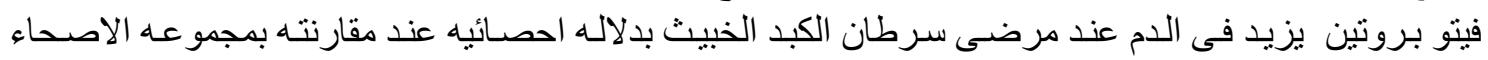

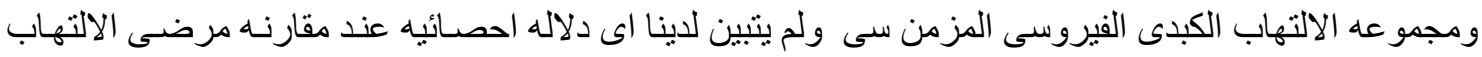

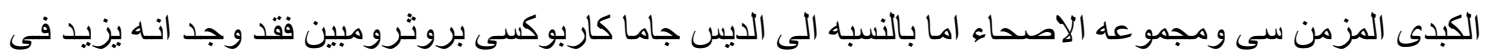

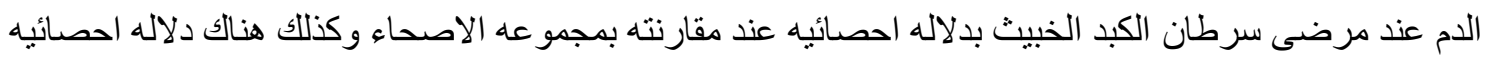

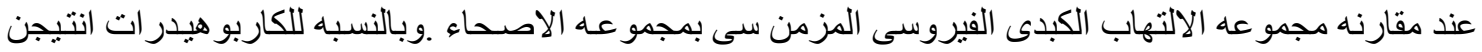

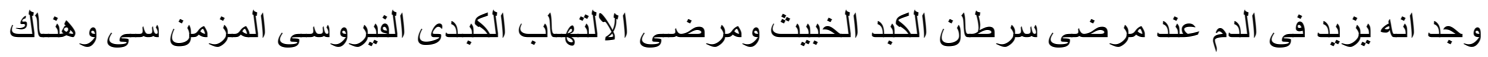

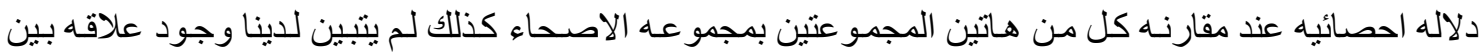

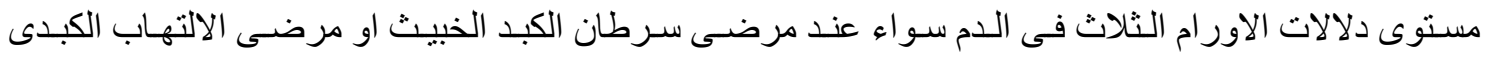

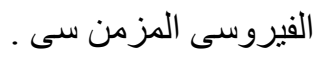

الملخص: اظهرت الدر اسـه ان الديس جامـا كاربوكسى بروثُرومبين و الكاربو هيدر ات انتيجن يمكن ان يستخدما

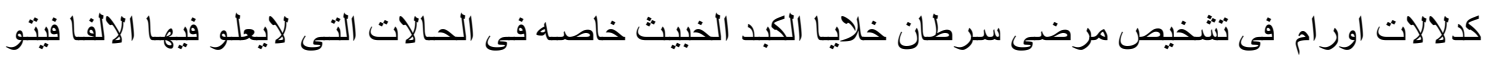

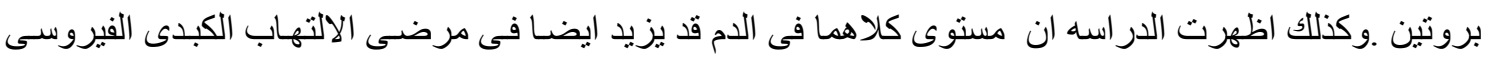

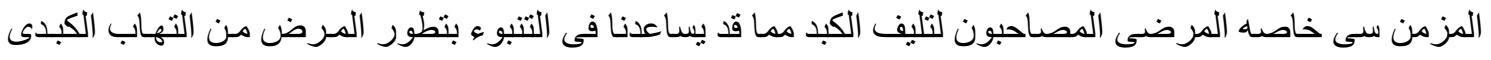
الفيروسى المزمن الى سرطان الخلايا الكبديه الخييث 